\title{
Strengthening The Religiosity of Students Through Collaborative Approach and Controlling System During The Covid-19 Pandemic
}

\author{
Ali Romadhon Songlap ${ }^{1}$, Wakhudin ${ }^{2}$ \\ \{ $\underline{\text { alisonglap08@gmail.com }}{ }^{1}$, wakhudin@ump.ac.id ${ }^{2}$ \} \\ ${ }^{1}$ SD Negeri Tritih Wetan 01, Jeruklegi, Cilacap \\ ${ }^{2}$ Magister Pendidikan Dasar, Universitas Muhammadiyah Purwokerto, \\ J1 KH Ahmad Dahlan, Banyumas 53182, Indonesia
}

\begin{abstract}
The background of this research is the lack of religious character in public schools during the Covid-19 pandemic. The purpose of this study is to describe whether using a collaborative approach and controlling system can strengthen the religious character of students in the pandemic era. This research is a qualitative research on the application of the collaborative approach and controlling system carried out by classroom teachers, religious teachers, parents, and the community to strengthen the religious character of the students of SDN Tritih Wetan 01 Cilacap.This study uses a phenomenological approach with John's W. Cresswell analytical method, with text and discourse interpretation techniques. Based on the results of the study, it was found that the application of the collaborative approach and controlling system can be implemented and can strengthen the religious character of students including students becoming more diligent, disciplined, and responsible, especially in worship. So it can be concluded that the collaborative approach and controlling system has proven to be able to strengthen religious character in the Covid-19 pandemic era.
\end{abstract}

Keywords: religious character, collaborative approach, controlling system

\section{Introduction}

Character is the most important part of Indonesia's education output as stated in the National Education System Law no. 20 of 2003 article 3. But the fact is that the results of education in Indonesia have not been in accordance with what was expected. Whereas religious character is very important, even the first precepts of Pancasila are based on the religious character, namely Belief in One God.

But in fact, schools have not really made the aspect of religiosity a priority in the curriculum or learning activities, especially in public or public schools. For example, from one class an average of $60-80 \%$ of students have not performed the five daily prayers and have not been able to read the Koran. This condition is evenly distributed in almost every class and in every school year. Even the lack of religious reinforcement in public schools is a phenomenon that is considered normal.

Some of the reasons for the lack of strengthening of religious character are the lack of hours in religious subjects, and the lack of maximum cooperation between classroom teachers, religious teachers, parents and the community.In fact, religious character is a shared 
responsibility. Reinforcement of religious character should also appear and be integrated with learning.Teachers should always insert messages, linking phenomena around or subject matter with spiritual aspects in their daily lives. Schools should also make religious habits a school culture. The habituation in question is certainly not just a ceremonial activity such as a celebration of praying before and after studying, but it must be more than that.

Habits such as praying, reading the Koran (reading the holy book) or giving alms also need to be familiarized with students. However, this condition is rarely implemented, including at SDN Tritih Wetan 01.But not only at school, strengthening religious character should also be carried out at home, considering the duration of time at school is less than at home. In addition, the lack of strengthening of religious characters is also due to weak supervision of the implementation of strengthening religious characters.Especially in the era of the Covid-19 pandemic where learning is done online. This condition makes it more difficult for teachers to supervise learning, including in the formation of students' religious character.

So the school's collaboration with parents and the community is important, there needs to be a collaborative approach.Collaborative approach is etymologically derived from the word "collaborative" which means collaborative and "approach" which means approach. "collaboration" can be interpreted as "joint effort toward a group goal" or a joint effort to achieve a common goal [1]. The practice of "collaboration" is one of the disciplines that has been widely used by social scientists "collaborative and its corresponding values and best practices have become a precise discipline that has been studied by social scientists for decades in the realm of organizations" [2]. Meanwhile, Frans \& Bursuck [3] defines "collaborative" namely "collaborative is a professional style chose to use in order to accomplish a goal they share.So from the description above it can be concluded that the collaborative approach is an approach in the form of cooperation chosen by professionals to achieve certain goals.

The collaborative approach is also in line with the principles of School-Based Management. The principle of School-Based Management is the involvement of various parties for the achievement of a school program as the goal of School-Based Management is to establish or empower schools through granting authority (autonomy) to schools to encourage schools to make participatory decision-making [4]. So the collaborative approach is expected to form a habit pattern that becomes a character.

In addition, there is also a need for a systematic monitoring (controlling system) for these strengthening activities so that student motivation is maintained.Controlling system comes from two words "controlling" and "system" which when combined into a clause means controlling system.Control system or early controlling was first developed in the United States, but developed in a modern way in Germany. Maryna Reta, Elena Druhova, and Oksana Lisnichuk define "The controlling system is an accounting and system, implementing the synthesis of analytical elements of accounting, control, planning, forecasting coordination, providing both operational and strategic management of goal achievement and enterprise's performance." [5].

According to Hanif Al Fatta that the system is a collection of interrelated objects and interacting relationships between objects can be seen as a single unit designed to achieve one goal [6]. Meanwhile, according to Assauri's definition, control and supervision are activities carried out to ensure that production and operating activities are carried out according to what is planned and if there are deviations, these deviations can be corrected, so that what is expected can be achieved [7]. So if it is interpreted in its entirety what is meant by a controlling system or control system in this study is a collaboration carried out by several parties to achieve certain goals in which there is supervision to achieve these goals, so that if there is a deviation it will be a correction for improvement. 
From the explanation above, researchers are interested in researching and describing how the process of strengthening religious character through a collaborative approach and controlling system for students at SDN Tritih Wetan 01 Cilacap in the current covid-19 pandemic era.

\section{Method of the Research}

The research method used in this study is a qualitative research method using a phenomenological approach. Phenomenology is a scientific method which assumes that the existence of a reality is unknown to people in ordinary experience. Phenomenology makes the experience that is actually lived as the basic data of a reality [8] Meanwhile, according to Cresswell (2013) [9] means that phenomenology is a narrative study that reports the experience of an individual or several individuals by describing general experiences of various life experiences related to concepts or phenomena-phenomenon.Phenomenological research is not too interested in the aspect of causality but focuses more on efforts to uncover how a person does an experience and the meaning of that experience for him.

As for the stages, first the researchers chose five students with three categories, namely the two most religious children, one medium child, and two least religious children.This selection was based on a survey and study of student documentation. After that, the researchers applied a collaborative approach and controlling system technique that involved classroom teachers, religious teachers, parents and the community.

The teacher's initial step is to provide materials, advice and instructions to carry out religious strengthening programs such as praying and reading the Koran. Then parents and the community supervise directly when students are at home.For control, a control book is made to motivate, supervise and evaluate character strengthening programs. The program is implemented for two months. The results of the program were then analyzed using the Phenomenology method with the Cresswell technique which was obtained based on interviews, observations and documentation studies. This research was conducted at SDN Tritih Wetan 01 which is located at Jalan Rawa Bendungan No.1 Tritih Wetan Village, Jeruklegi District, Cilacap Regency. As for the subject of research is class VI students. While the time of the study was carried out in March-April 2021.

The structured analysis technique of Phenomenology of Creswell, J.W [10] is as follows:

2.1 Describe personal experience with the phenomenon being studied. The researcher begins with a complete description of his experience with the phenomenon. This is an attempt to get rid of the researcher's personal experience (which cannot be done completely) so that the focus can be directed on his participation in the study.

2.2 Make a list of important statements. The researcher then finds statements (in interviews or other data sources) about how individuals experience the topic, lists these important statements (horizontalization of the data) and assumes each statement has an equivalent value, and works to compile a list of statements that are non-repetitive and non-repetitive. overlap.

2.3 Take these important statements, then group them into larger units of information, which are called "meaning units" or themes.

2.4 Write a description of the "what" experienced by the participants with the phenomenon. This is called a "textural description" of the experience-what happened and includes verbatim examples. 
2.5 Write a description of "how" the experience happened. This is called a "textural description" and the researcher discusses the setting and context in which the phenomenon is experienced.

2.6 Write a composite description of the phenomenon by including a textural description and a structural description. This section is the "essence" of the experience and presents the pinnacle aspect of phenomenological studies. This is usually a long paragraph telling the reader "what" participants experienced with the phenomenon and "how" they experienced it (ie, the context).

In this study, the validity test was carried out by conducting a credibility test using data triangulation techniques.Moleong, L.J. [11] explained that triangulation is a data validity checking technique that utilizes something else. Meanwhile, what is used in this study is the triangulation of Sugiyono's data, namely the triangulation of sources and techniques [12].

Triangulate resources with religion teachers, parents, and students. While triangulation techniques with interviews, observations, and documentation studies. This study also performs a dependability test or what is called a reliability test. In this study, the dependability test was carried out by conducting an audit of all research processes. The audit was carried out by the auditor, namely the supervisor of this research.

\section{Result and Discussion}

After implementing the collaborative approach program and controlling system, interviews were conducted to find out the results of the program. These results can be seen as follows.

Question 1: How does religionimportant for you?

Following informant answer quotations.

"Important, because otherwise there alive aim religion not directional" (Novrain. Wan. 00.32).

"Important, because with strong belied strong will face alive test" (Madu. Wan. 00.11).

"Important, because very useful when we are in distress" (Easy. Wan. 00.49).

"Important, because with my religion sues to learn worship and do a kindness, be to know which good which not, be a guide to life"(Fabil. Wan. 00.13).

"Important, because can determine life either in the world or at afterlife"(Fecia. Wan. 01.46).

Interpretation:

Actually, this question seeks to express in a simple way the meaning of religion for students, and this question is also related to the meaning of the religious character strengthening program under study. From the question it was revealed that all students revealed that religion is something important in their lives. Religion clarifies the purpose of life, as a strength to face trials and tribulations, can distinguish what is good and what is not and is also beneficial for their afterlife.

Question 2: How do feeling you towards this religious character reinforcement program?

Following informant answer quotations.

"I felt glad bot because of force because the heart is calm and near to Allah (Novrian. Wan. 09.34).

"I felt glad because so discipline and add spirit so that the prayer alwayssues five times and recite so diligent" (Madu. Wan. 08.01).

"I felt glad, so more spirit" (Easy. Wan. 08.10).

"I felt there the benefit, I so diligence so on time in prayer, I felt their change sues not difficult, so discipline increase spirit" (Fabil. Wan. 04.20). 
"I am honest felts glad, so regulate so not lazy" (Fabil. Wan. 06.48).

"I felt glad so to add prayer spirit, recite" (Fecia. Wan. 05.25). "I felt glad so to add spirit" (Fecia. Wan. 07.15)

\section{Interpretation:}

The character strengthening program with a collaborative approach and controlling system makes students feel happy, meaning that it is not too burdensome for students and can be carried out and the feeling of pleasure is because of changes for the better that are felt by students. The program makes students more diligent, enthusiastic, and disciplined in carrying out worship which has an impact on students' peace of mind. This was also revealed by FA's parents in another interview that the FA even waited for the prayer time (adhan) when doing worship activities, something that did not happen before the program.

Question 3: How do you carry out this program? “

Following informant answer quotations.

"Moment carry out teacher reminds, parents especially also remind mother. There change formerly sometimes forget prayer now issuing diligent religious service" (Novrain. Wan. 05.28). "In carrying out this program often reminds mother father, teacher recites, teacher" (Madu. Wan. 06.17). "For signature usually ask all at once" (Madu. Wan. 10.24).

"This program often reminds mother, father via call every day, teacher via group whatsapp" (Easy. Wan. 06.15).

"This program often reminds mother, elder brother, teacher via group Whatsapp" (Fabil. Wan. 04.29).

"This program is that signature is mother, support does not know because of support Christian" (Fecia. Wan. 04.27).

"Mother usually remind this program, also teacher" (Fecia. Wan. 06.32)

Interpretation:

The character strengthening program with a collaborative approach and controlling system can be carried out properly, this is revealed from the statements of students, both parents, classroom teachers and religious subjects teachers can collaborate well and the controlling system can be implemented with material and advice from teachers which then parents make basic to be able to supervise, remind students. The control book is an effective means of controlling the system as an indirect supervisor who can maintain the enthusiasm of students in strengthening religious characters during the Covid-19 pandemic.

Question 4: Tell experience that leaves an impression during this program execution!

Following informant answer quotations.

"There experience has been reprimanded mother flutter summons to prayer not yet prayer" (Novrain. Wan. 10.54).

"When is dawn difficult fit get up father haul my foot and also younger brother then splatter water, so that get up" (Madu. Wan. 07.01).

"There change after that program, I so diligent" (Easy. Wan. 06.56).

"When does prayer at Mushola then the friend invite to joke, then my mother knows, then I am hit angry ordered to repeat" (Fabil. Wan. 02.46).

"Mother sues a more regular reminds after that program existence (Fabil. Wan. 05.49) 
"I am the dawn prayer runs low perforated, formerly often" (Fecia. Wan. 04.19). "There my change adds to so diligent and discipline although sometimes still there perforated" (Fecia. Wan. 06.05).

\section{Interpretation:}

From the answers to these questions, it reinforces that the program for strengthening religious characters with a collaborative approach and controlling system can really be implemented and all students feel a change from the attitude of parents, namely parents become more active and persuasive, some are even quite "radical" to make the program successful. . Of course this has a positive impact on strengthening the religious character of students.

The explanation above illustrates that the process of strengthening religious character is important for students. Program collaborative approach and controlling system between classroom teachers, religious teachers, and parents to strengthen the religious character of students can also be implemented and proven to provide changes to the religious character of students. Students become more enthusiastic, orderly, and disciplined in carrying out worship. It also has an impact on the peace of their hearts and souls.

\section{Conclusion}

Religious character is the most important character of the other characters. One of the efforts that can be made to strengthen the religious character of elementary school students in the era of the Covid-19 pandemic is the collaborative approach and controlling system. The program for strengthening religious character with a collaborative approach and controlling system can be implemented. Feelings of pleasure and memorable experiences while implementing this program also make this program more meaningful for students.

The application of the collaborative approach technique and controlling system has been proven to be able to provide quite good changes to the character of students, the religious character of students is increasing, especially in terms of religious obedience. Students become more enthusiastic, diligent, disciplined and responsible in carrying out worship

\section{References}

[1] Ningrum, D. (2018). Kemerosotan moral di kalangan remaja: Sebuah penelitian mengenai parenting styles dan pengajaran adab. Unisia, 37(82), 18-30..

[2] Ilham. (2016). 97 Persen Remaja Indonesia Pernah Mengakses Pornografi. Retrieved 24/12/2020 from https://republika.co.id/berita/nasional/hukum/16/10/11/oew0yb361-97persen-remaja-indonesia-pernah-mengakses-pornografi

[3] Hakim, R. N. (2020). Kompas.com. Retrieved 24/12/2020 Jam 23.20 from https://nasional.kompas.com/read/2020/12/11/17120821/saat-presiden-jokowi-gamangsikapi-2-menterinya-yang-terjerat-kasus-korupsi?page=all.

[4] Suyitno, Y. (2017). Pedagogika Teoritis dan Praktis. Universitas Pendidikan Indonesia.

[5] Mulyadi, B. (2014). Model pendidikan karakter dalam masyarakat Jepang. Izumi, 3(1), 6980.

[6] RAMADHAN, K. (2019). Studi Analisis Terhadap Implementasi Nilai Ketuhanan Yang Maha Esa Dalam Pancasila Ditinjau Dari Fiqih Syisah (Doctoral dissertation, UIN Raden Intan Lampung).

[7] Hadi, N. F. (2018). Mendesain Bangsa Yang Religius dan Nasionalis dari Bangku Sekolah. Tazkir: Jurnal Penelitian Ilmu-ilmu Sosial dan Keislaman, 4(1), 41-70. 
[8] Randrup, N., Druckenmiller, D., \& Briggs, R. O. (2016). Philosophy of collaboration. 2016 49th Hawaii International Conference on System Sciences (HICSS)

[9] Prange, K., Allen, J. A., \& Reiter-Palmon, R. (2016). Collective impact versus collaboration: sides of the same coin or different phenomenon?. Metropolitan universities, 27(1), 86-96.

[10] Creswell, J.W. 2015. Penelitian Kualitatif \& Desain Riset. Yogyakarta : Pustaka Pelajar

[11] Moleong J.L. 2011 Metodologi Penelitian Kualitatif,Eds.. Bandung:PTRemajaRosdakarya

[12] Sugiyono. (2012). Metode Penelitian Pendidikan Pendekatan Kuantitatif, Kualitatif, dan $R$ $\& D$. Alfabeta. 